\title{
Evaluation of a heating block system for accurate temperature-time controlled pasteurization treatments on various foods
}

\author{
Xiaoxi Kou ${ }^{1}$, Rui Li ${ }^{1}$, Lixia Hou ${ }^{1}$, Teng Cheng ${ }^{1}$, Xu Zhou ${ }^{1}$, Shaojin Wang ${ }^{1,2^{*}}$ \\ (1. College of Mechanical and Electronic Engineering, Northwest A\&F University, Yangling 712100, Shaanxi, China; \\ 2. Department of Biological System Engineering, Washington State University, Pullman, WA 99164-6120, USA)
}

\begin{abstract}
For simulating real pasteurization treatments using hot air, hot water, radio frequency and microwave heating, a unique experimental heating block system (HBS) was developed. The stability and uniformity of sample temperatures and heating rates in HBS were determined for studying the thermal resistance of food-borne pathogens. A computer simulation model was also developed to analyze the behavior of thermal process in HBS. The results showed that the required heating rates with various set-temperatures and holding times could be easily and precisely achieved in eight selected food materials. Thermocouple and thermal imaging data showed that the good sample heating uniformity in six cells of HBS was achieved. The real temperature-time histories obtained by radio frequency energy could be approximately done in HBS by setting a number of linear regression curves. The HBS can help in more precisely characterizing the heat resistance of pathogens in foods to further develop pasteurization processes.
\end{abstract}

Keywords: thermal treatment, heating rate, heating uniformity, thermal resistance, simulation, heating block system (HBS) DOI: $10.25165 /$ j.ijabe.20181103.3734

Citation: Kou X X, Li R, Hou L X, Cheng T, Zhou X, Wang S J. Evaluation of a heating block system for accurate temperature-time controlled pasteurization treatments on various foods. Int J Agric \& Biol Eng, 2018; 11(3): 220-228.

\section{Introduction}

The potential contamination in food or food ingredients caused by food-borne pathogens, such as Salmonella and Listeria monocytogenes, has attracted increasing attentions from the food processing industry all over the world ${ }^{[1,2]}$. Thermal processing technologies including conventional and novel thermal processing, which are proposing to be non-chemical alternative method for pasteurization of food-borne pathogens, have been widely used in the laboratory research and food industry ${ }^{[3-5]}$. Proper design of thermal processes requires comprehensive understanding of thermal impacts on quantitative changes of food quality and thermal resistance of target food-borne pathogens ${ }^{[6-8]}$. Thermal resistance of food-borne pathogens has to be determined under isothermal conditions for developing effective thermal treatments $^{[9,10]}$.

Except for thermal properties of foods, final temperatures and holding times, heating rates have a significant effect on thermal resistance of given food-borne pathogens because of their metabolism and physiological adjustment. Slow heating rates enhance thermal resistance of food-borne pathogens with large

\section{Received date: 2017-08-21 Accepted date: 2018-03-08}

Biographies: Xiaoxi Kou, MSc, Lecturer, research interests: processing of agricultural products, Email: kousissy@126.com; Rui Li, MSc, research interests: processing and storage of agricultural products, Email: ruili1216@nwsuaf.edu.cn; Lixia Hou, PhD, research interests: processing and storage of agricultural products, Email: hlx0924hyx@163.com; Teng Cheng, BSc, research interests: pasteurization in thermal food processes, Email: 1192838167@qq.com; Xu Zhou, BSc, research interests: radio frequency drying, Email: 405970173@qq.com.

*Corresponding author: Shaojin Wang, PhD, Professor, research interests: processing and storage of agricultural products, disinfestation and pasteurization of postharvest products using radio frequency heating. College of Mechanical and Electronic Engineering, Northwest A\&F University, Yangling 712100, China. Tel: +86-29-87092319; Fax: +86-29-87091737; Email: shaojinwang@ nwsuaf.edu.cn.
$D$-values under same target temperatures ${ }^{[11-13]}$. For example, $D$-values of Salmonella at $60^{\circ} \mathrm{C}$ are different in the same host food because of the different samples size ${ }^{[14,15]}$. The different thermal resistance of Escherichia coli has been reported owing to using the different test tube materials, such as glass or aluminum ${ }^{[9,16]}$. Due to the differences in heating principle and mode, the common thermal processes, such as steam, hot air, hot water, radio frequency (RF) and microwave (MW), have different heating rates during thermal treatment ${ }^{[17-19]}$. These treatments would not meet the required efficacy if the thermal resistance of target food-borne pathogens was obtained under a fixed heating rate using traditional thermal-death-time (TDT) test devices in water or oil bath. The heating rates in the above-mentioned devices could not be exactly controlled during the experiment since those are dependent on thermal properties of both test devices and food materials.

For simulating the real pasteurization process by using hot air, hot water, steam, RF and MW energy, a unique experimental TDT heating block system (HBS) has been developed for investigating thermal resistance of food-borne pathogens ${ }^{[20]}$. The sample placed in the HBS can be controlled to obtain different heating rates, final temperatures, and holding times and provide an isothermal heating environment for pathogen's inactivation. However, the test food samples in our previous research are limited that only one of six cells (sample holders) was monitored to describe the real-time temperature histories and temperature uniformity ${ }^{[20]}$. Stability of temperatures and heating rates in samples are important characteristics for the HBS. If temperature difference is larger than $1{ }^{\circ} \mathrm{C}$ during thermal process and holding time, it may affect the thermal response of target food-borne pathogens ${ }^{[11,21]}$. Therefore, several kinds of food samples, such as liquid, semi-solid, and solid samples with various thermal properties, need to be covered to further determine the performance characteristics of HBS and potential applications to simulate real sample temperature profiles obtained by advanced heating methods.

Because experimental methods to determine the effects of 
multiple factors are time consuming and costly, computer simulation has been used to predict temperature distributions and heating uniformity in various food samples under different conditions. Chung et al. ${ }^{[12]}$ used FEMLAB to evaluate the performance of aluminum test cells. Yan et al. ${ }^{[22]}$ optimized the thermal treatment conditions of the CA-HBS by COMSOL. Huang et al. ${ }^{[23,24]}$ developed a 3-D theoretical model using COMSOL to determine differential heating of insects in soybeans when subjected to RF treatments. Therefore, the finite element computer simulation may provide a useful tool to analyze the heating uniformity in the HBS and predict thermal process in samples without conducting lengthy experiments.

The objectives of this study were to: (1) evaluate performance of the HBS with eight different food samples at three set temperatures under three heating rates, (2) analyze the heating uniformity in all six-cell samples, (3) develop and validate a simulation model for the HBS using the finite element software COMSOL, and (4) simulate the real temperature-time history from a RF thermal process using the HBS.

\section{Materials and methods}

\subsection{Description of the TDT heating block system}

The HBS was consisted of a heating unit, a data acquisition/control unit and a computer (Figure 1a). The heating unit $(28 \mathrm{~cm} \times 30 \mathrm{~cm} \times 13.5 \mathrm{~cm})$ included top and bottom blocks, heating pads and 6 pull-push boxes with 6 TDT cells. The 6 TDT cells were just fitted in the pull-push boxes, which were located in the bottom block and distributed uniformly (Figure 1b). The box could be easily pushed into the block for heating and pulled out for fast cooling in ice water. The TDT cell cavity was $20.6 \mathrm{~mm}$ in diameter and $3 \mathrm{~mm}$ in height, providing a sample space of $1.00 \mathrm{~mL}$ (Figure 1c).

The HBS was controlled by a data acquisition/control unit $(28 \mathrm{~cm} \times 30 \mathrm{~cm} \times 14.5 \mathrm{~cm})$. The temperatures of one sample and two blocks were measured by calibrated Type-T thermocouples (TMQSS-020-6, Omega Engineering Ltd., CT, USA). Heating rate, set-point temperature, and holding time were controlled by the customized Visual Basic software and two proportional-integralderivative (PID) controllers (I32, Omega Engineering, Inc., Stamford, CT, USA) via a solid-state relay. Detailed descriptions of the HBS can be found in Kou et al. ${ }^{[20]}$

\subsection{Stability of controlled temperature levels}

\subsubsection{Test samples}

To study the heat effect of different samples during the thermal process, apple juice, milk, rice paste, rice, egg white, peanut powder, peanut butter and ground beef were chosen as representative liquid, semi-solid and solid foods. These eight materials were commonly used to cover three sample states and various thermal properties.

Apple juice (Huiyuan 100\% Apple Juice, Yangling, China) and whole milk (Mengniu natural pure milk, Hohhot, China) were purchased from a local supermarket and stored in a refrigerator (BD/BC-297KMQ, Midea Refrigeration Division, Hefei, China) at $(3 \pm 1)^{\circ} \mathrm{C}$ until use within the expiry date indicated by the manufacturer. Milled rice (Oryza sativa L.), shelled peanuts and eggs were obtained from a local grain and oil grocery store in Yangling, Shaanxi, China, and refrigerated at $(3 \pm 1)^{\circ} \mathrm{C}$ before the experiment. Shelled peanuts and part of rice were milled with a grinder, and passed through a No. 18 mesh (16 Tyler). Then the

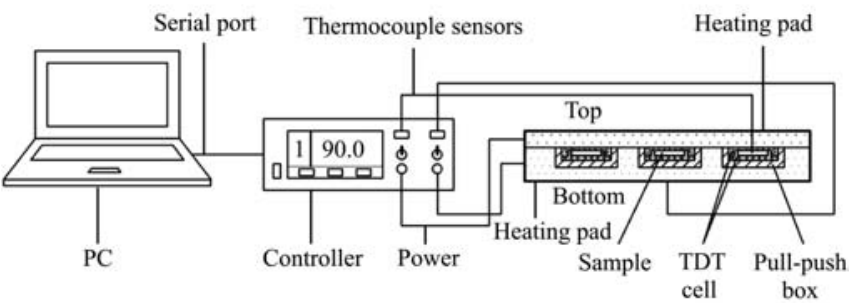

a. TDT heating block system

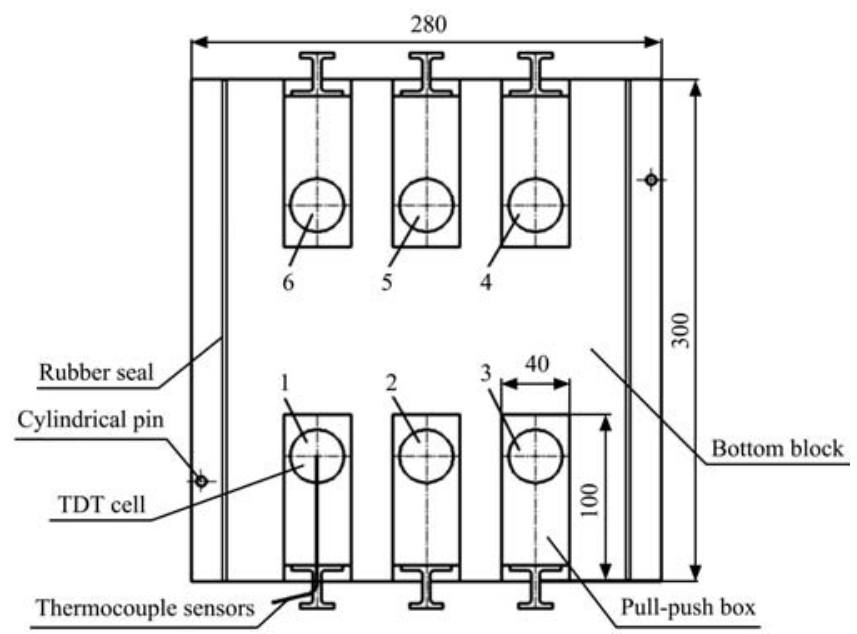

b. Top view of the 6 TDT cells

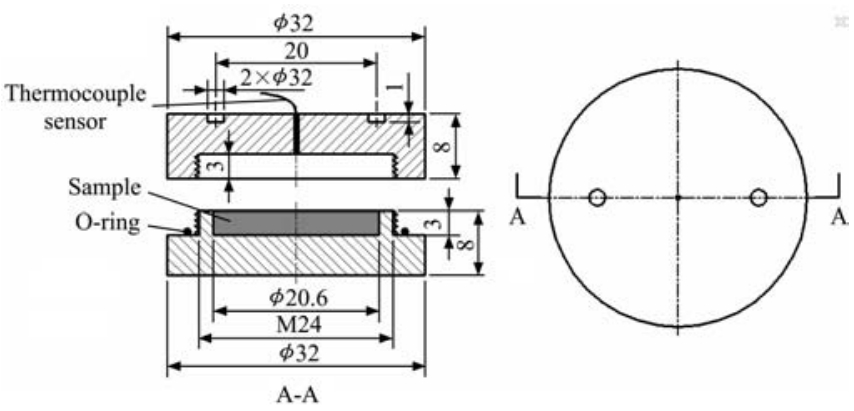

c. Detailed cross-section view of a TDT test cell

Note: all dimensions in $\mathrm{mm}$

Figure 1 Schematic diagram of the general TDT heating block system $^{[20]}$

dry rice powder was mixed with distilled water to formulate into $46.14 \%$ wet basis (w.b.) rice paste. The peanut butter (Skippy, Hormel Foods, Shanghai, China) was purchased at Metro AG (Xian, Shaanxi, China) and stored at room temperature of $22^{\circ} \mathrm{C}$. Raw ground beef $(90 \%$ lean), obtained from a local store, was placed in zip-lock bags, under vacuum-sealed, and frozen at $-20^{\circ} \mathrm{C}$.

Density $\rho\left(\mathrm{kg} / \mathrm{m}^{3}\right)$ of eight samples were obtained by samples weight in the cell. Specific heat $c_{p}\left(\mathrm{~J} / \mathrm{kg} \cdot{ }^{\circ} \mathrm{C}\right)$ and thermal conductivity $k\left(\mathrm{~W} / \mathrm{m} \cdot{ }^{\circ} \mathrm{C}\right)$ were measured by a thermal property analyzer (KD2 Pro, Decagon Inc., Pullman, WA, USA) based on the transient line heat source method. The KD2 pro contains a single needle KS-1 sensor (60 mm long, and $1.3 \mathrm{~mm}$ in diameter), and a dual needle SH-1 sensor (30 mm long, $1.28 \mathrm{~mm}$ in diameter, and $6 \mathrm{~mm}$ spacing), attached to a handheld readout unit. The samples were added into $150 \mathrm{~mL}$ glass beaker, and the weight of samples was calculated by the volume of the beaker and the same density as in the cell test. The KD2 pro had an accuracy of $5 \%$ during the temperature range of $(0-40)^{\circ} \mathrm{C}$, and samples were kept at $25^{\circ} \mathrm{C}$ in a water bath (SC-15, Ningbo Scientz Biotechnology Co., Ltd., Ningbo, China). For liquid samples, we followed the instruction of this laboratory equipment and the low power mode 
was set to reduce the effect of convection. The SH-1 sensor was used for the solid or semi-solid samples, while the KS-1 sensor could be used for liquid samples. Each experiment was replicated three times.

\subsubsection{Heat treatment procedures}

To verify the device's performance of controlling the heating rates, set temperatures, and holding times precisely, three target temperatures at three heating rates of $1^{\circ} \mathrm{C} / \mathrm{min}, 5^{\circ} \mathrm{C} / \mathrm{min}$ and $10^{\circ} \mathrm{C} / \mathrm{min}$ were selected for each food sample.

A sample of $1 \mathrm{~mL}$ of apple juice was placed into the TDT cell at room temperature, then the block temperature was raised to $50^{\circ} \mathrm{C}$, $70^{\circ} \mathrm{C}$ and $90^{\circ} \mathrm{C}$ at $1{ }^{\circ} \mathrm{C} / \mathrm{min}, 5^{\circ} \mathrm{C} / \mathrm{min}$ and $10^{\circ} \mathrm{C} / \mathrm{min}$, respectively, and held at that temperature for $1 \mathrm{~min}^{[25,26]}$. For $1 \mathrm{~mL}$ milk, the temperature was set to $50^{\circ} \mathrm{C}, 62.2^{\circ} \mathrm{C}$ and $75^{\circ} \mathrm{C}^{[18,27]}$. The temperature was selected as $50^{\circ} \mathrm{C}, 70^{\circ} \mathrm{C}$ and $90^{\circ} \mathrm{C}$ for $0.8 \mathrm{~g}$ rice ${ }^{[28,29]}$, and $44^{\circ} \mathrm{C}, 50^{\circ} \mathrm{C}$ and $70^{\circ} \mathrm{C}$ for $1.4 \mathrm{~g}$ rice paste. Because of the stability states, $1.0 \mathrm{~g}$ peanut powder and $1.3 \mathrm{~g}$ peanut butter's experiment temperature was chosen of $50^{\circ} \mathrm{C}, 75^{\circ} \mathrm{C}$ and $100^{\circ} \mathrm{C}^{[2,30]}$. For $1.1 \mathrm{~g}$ egg white, the temperature was of $46^{\circ} \mathrm{C}, 55^{\circ} \mathrm{C}$ and $66^{\circ} \mathrm{C}^{[31,32]}$, and for $1.0 \mathrm{~g}$ thawed beef was of $50^{\circ} \mathrm{C}, 70^{\circ} \mathrm{C}$ and $120^{\circ} \mathrm{C}^{[33,34]}$. All heat treatments followed the same procedure.

\subsection{Heating uniformity}

Peanut powder was chosen for heating uniformity studies since it had a smaller thermal conductivity and slower heating rate among these eight food samples discussed in sections 3.2 and 3.3 (Tables 1 and 2). Two methods were used to measure the uniformity of heating. The first was using the thermocouples in one sample, and the second was using an IR thermal imaging camera (ThermaCam A3X0, FLIR Systems AB, Stockholm, Sweden).

Table 1 Measured thermal properties at $25^{\circ} \mathrm{C}$ used in the simulation

\begin{tabular}{|c|c|c|c|}
\hline Material & $\rho / \mathrm{kg} \cdot \mathrm{m}^{-3}$ & $c_{p} / \mathrm{J} \cdot\left(\mathrm{kg} \cdot{ }^{\circ} \mathrm{C}\right)^{-1}$ & $k / \mathrm{W} \cdot\left(\mathrm{m} \cdot{ }^{\circ} \mathrm{C}\right)^{-1}$ \\
\hline Apple juice & 1047 & 3992 & 0.52 \\
\hline Milk & 1032 & 4050 & 0.56 \\
\hline Rice paste & 1400 & 2763 & 0.66 \\
\hline Rice & 803 & 1750 & 0.15 \\
\hline Egg white & 1105 & 3391 & 0.94 \\
\hline Peanut powder & 1000 & 1974 & 0.22 \\
\hline Peanut butter & 1300 & 1339 & 0.21 \\
\hline Ground beef & 1000 & 3220 & 0.31 \\
\hline Aluminum block $^{[39]}$ & 2702 & 903 & 234.00 \\
\hline
\end{tabular}

Table 2 Maximum heating rates in food samples and temperature differences between experiment and simulation

\begin{tabular}{cccc}
\hline Material & $\begin{array}{c}\text { Maximum heating } \\
\text { rate } /{ }^{\circ} \mathrm{C} \cdot \mathrm{min}^{-1}\end{array}$ & $\begin{array}{c}\text { Average } \\
\text { temperature } \\
\text { differences } /{ }^{\circ} \mathrm{C}\end{array}$ & $\begin{array}{c}\text { Maximum } \\
\text { temperature } \\
\text { differences } /{ }^{\circ} \mathrm{C}\end{array}$ \\
\hline $\begin{array}{c}\text { Apple juice } \\
\text { Milk }\end{array}$ & 12.7 & 0.16 & 0.94 \\
Rice paste & 13.1 & 0.10 & 0.39 \\
Rice & 12.4 & 0.15 & 0.94 \\
Egg white & 11.2 & 0.16 & 0.67 \\
Peanut powder & 11.6 & 0.19 & 0.81 \\
Peanut butter & 12.0 & 0.16 & 0.86 \\
Ground beef & 11.8 & 0.15 & 0.86 \\
\hline
\end{tabular}

\subsubsection{Thermocouple method}

To evaluate the temperature uniformity, a sample temperature in the center of the TDT-cell was measured by the Type- $T$ thermocouple sensor during the heating treatments. Same sample temperatures were measured in the other five cells by following the same procedure. The sample temperature and heating rate were set at $70^{\circ} \mathrm{C}$ and $10^{\circ} \mathrm{C} / \mathrm{min}$. The experiment was replicated twice.

\subsubsection{Thermal imaging method}

The thermal imaging camera was used to map the surface temperatures of the samples after a heating treatment. Based on the calibration, the emissivity of the product in the camera was selected to be 0.94 . Images were taken from a distance of approximately $70 \mathrm{~cm}$ from the block system. The images were transmitted to a computer and analyzed with a matched software (BM-IR, FLIR Systems AB, Stockholm, Sweden) and SigmaPlot 12.0 (Systat Software, Inc., San Jose, CA, USA). The sample temperatures were set at $50^{\circ} \mathrm{C}, 70^{\circ} \mathrm{C}$ and $90^{\circ} \mathrm{C}$ with a heating rate of $10^{\circ} \mathrm{C} / \mathrm{min}$, respectively. The thermal image was taken within $12 \mathrm{~s}$ after the top block was removed from the apparatus immediately after heating. The experiment was replicated twice. 2.3.3 Uniformity index $(\lambda)$

Uniformity index $(\lambda)$ is a useful parameter to estimate temperature distributions of treated samples. The $\lambda$ value has been successfully used for evaluating RF heating uniformity and can be calculated by the following equation ${ }^{[35]}$ :

$$
\lambda=\Delta \sigma / \Delta \mu
$$

where, $\Delta \sigma$ and $\Delta \mu$ are the rise in the standard deviation and mean values, ${ }^{\circ} \mathrm{C}$, respectively, from the initial to final sample temperatures over treatment time, ${ }^{\circ} \mathrm{C}$. Smaller $\lambda$ values represent better heating uniformity ${ }^{[29]}$.

\subsection{Finite element model and simulation}

A heat transfer model was used to simulate the thermal process of the $\mathrm{HBS}^{[22]}$. The HBS was modeled as a three-component system consisting of two aluminum blocks and six cell samples. The heating pads were set as boundary heat sources. The heat fluxes transferred from heating pads to top and bottom blocks and then to the cell and sample through heat conduction. Table 1 summarizes the properties of the various materials used in the computer simulations.

Transient heat transfer through the block and sample was governed by the following differential equation:

$$
\rho C_{p} \frac{\partial T}{\partial t}=k\left(\frac{\partial^{2} T}{\partial x^{2}}+\frac{\partial^{2} T}{\partial y^{2}}+\frac{\partial^{2} T}{\partial z^{2}}\right)
$$

where, $\rho$ is the mass density of the material, $\mathrm{kg} / \mathrm{m}^{3}, C_{p}$ is the specific heat capacity, $\mathrm{J} /\left(\mathrm{kg} \cdot{ }^{\circ} \mathrm{C}\right), k$ is the thermal conductivity, $\mathrm{W} /\left(\mathrm{m} \cdot{ }^{\circ} \mathrm{C}\right), T$ is the temperature, ${ }^{\circ} \mathrm{C}, t$ is the time, $\mathrm{s}$, and $x, y$, or $z$ is the Cartesian coordinate position, $\mathrm{m}$.

Heat flux $(q), \mathrm{W} / \mathrm{m}^{2}$, from the heating pad, in the direction normal to the interfaces between the top and bottom blocks and the heating pads is described by the following:

$$
-k \frac{\partial T}{\partial n}=q
$$

where, $n$ is the outward normal direction to surface. Convective heat transfer at the block edge normal to the side was given by:

$$
-k \frac{\partial T}{\partial n}=h\left(T-T_{a}\right)
$$

where, $h$ value of $5 \mathrm{~W} /\left(\mathrm{m}^{2}{ }^{\circ} \mathrm{C}\right)^{[22]}$ is the surface heat transfer 
coefficient, and $T_{a}$ is the ambient air temperature, ${ }^{\circ} \mathrm{C}$. The boundary heat source from the heating pads provides different heating flux $\left(q_{i}\right)$, which is influenced by heating rates and block thicknesses, and could be calculated as follows:

$$
q_{i}=60 k^{\prime} \rho C_{p} d_{i} \quad(i=1,2)
$$

where, $k^{\prime}$ is the heating rates, ${ }^{\circ} \mathrm{C} / \mathrm{min}$, and $d_{1}$ and $d_{2}$ are the thickness of the top $(16 \mathrm{~mm})$ and bottom blocks $(24 \mathrm{~mm})$, respectively.

The models were implemented in COMSOL Multiphysics software (V4.4a, COMSOL, Co., LTD., Shanghai, China) based on a finite element method. A Lenovo A4600k computer with two Dual Core i5-2400, $3.00 \mathrm{GHz}$ Xeon processors and 4 GB RAM equipping a Windows 8 64-bit operating system was used to run the software. A physics-controlled mesh was created. The time-dependent solver of UMFPACK with an absolute tolerance of 0.01 was used to solve the heat transfer equations (Equations. (2)-(5)). The time step was set as $0.1 \mathrm{~min}$, and a relative tolerance was 0.01 . Total solution time varied from 5-10 min, depending on the simulation sequence and specific conditions.

\subsection{System simulation for RF treatment}

A $6 \mathrm{~kW}, 27.12 \mathrm{MHz}$ parallel plate RF heating system with a free-running oscillator (COMBI 6-S, Strayfield International Limited, Wokingham, UK) was used in this study for walnut heating experiments. About $1 \mathrm{~kg}$ of dry walnuts, bought from a local store, was placed into a rectangular container positioned at the center of the bottom plate between the two electrodes. A fibre optical sensor (HQ-FTS-D120, Xi'an HeQi Opo-Electronic Technology Co., LTD, Shaanxi, China) with an accuracy of $\pm 0.5^{\circ} \mathrm{C}$ was used and placed in the center of the sample to monitor the temperature change versus time. The temperature-time history was recorded by the connected data logger (FTS-P104, Xi' an HeQi Opo-Electronic Technology Co., LTD, Shaanxi, China). The target-temperature was set to $75^{\circ} \mathrm{C}$. Then $\mathrm{RF}$ heated walnut kernel was milled with a grinder, and weighed $1 \mathrm{~g}$ to make the sample for the HBS. The non-linear temperature-time history in RF heated samples was divided into three sections for approximate linear regression curves. These three-section processes were continuously operated by the HBS with different set-temperatures $\left(40^{\circ} \mathrm{C}, 60^{\circ} \mathrm{C}\right.$ and $\left.75^{\circ} \mathrm{C}\right)$ and heating rates $\left(6.6^{\circ} \mathrm{C} / \mathrm{min}, 5.4^{\circ} \mathrm{C} / \mathrm{min}\right.$ and $\left.3.0^{\circ} \mathrm{C} / \mathrm{min}\right)$. The temperature control accuracy was determined by comparing the obtained temperature-time history curve in HBS with the RF heating results.

\subsection{Statistical analysis}

The mean values of temperatures measured by IR thermal camera were analyzed and drawn by SigmaPlot 12.0 (Systat Software, Inc., San Jose, CA, USA).

\section{Results and discussion}

\subsection{Thermal properties of the samples}

Thermal properties (specific heat and thermal conductivity) of the samples are related to the performance of the HBS, and used in the simulation. Table 1 lists the measured values of density, specific heat and thermal conductivity for the samples at $25^{\circ} \mathrm{C}$. Among the eight food materials, apple juice and milk are liquid, and specific heat and thermal conductivity are a litter higher than those of solid materials, such as rice, peanut powder, peanut butter and ground beef, which are in good agreement with the data in Krokida et al. ${ }^{[36]}$. Rice is a representative solid food with high porosity, and thermal energy transport is less effective due to a lowest thermal conductivity ${ }^{[36,37]}$. Thermal conductivities of peanut powder, peanut butter and ground beef were also low, mainly because thermal conductivity decreases linearly with increase in fat contents ${ }^{[36-38]}$. The various thermal properties would lead to the different performance during the heating process, but the PID algorithm could also precisely control the heating parameters in each sample.

\subsection{Heating performance of the $\mathrm{HBS}$}

Figure 2 shows experimental temperature-time histories of apple juice, milk, rice paste, rice, egg white, peanut powder, peanut butter and ground beef in the HBS under three set-temperatures at three heating rates. The heating rate and final temperature of the HBS were controlled well as reported by Kou et al. ${ }^{[20]}$ and Ikediala, et al. ${ }^{[39]}$ Compared with the theoretical temperature data, the average temperature differences were no larger than $0.25^{\circ} \mathrm{C}$, as shown in Table 2. From the experimental data, a minimum temperature difference was observed in milk between all the samples, and maximum one in beef. Table 3 shows in detail the maximum and average temperature differences in milk and beef samples at three different temperatures and heating rates during the experiment. The temperature differences were proportional to the heating rates and set-temperatures. Especially in low heating rates and set-temperatures, for example, the average temperature differences in milk and beef were $0.03^{\circ} \mathrm{C}$ with heating rate of $1{ }^{\circ} \mathrm{C} / \mathrm{min}$ at $50^{\circ} \mathrm{C}$. The maximum temperature differences $\left(0.97^{\circ} \mathrm{C}\right)$ when heated beef to $120^{\circ} \mathrm{C}$ at $10^{\circ} \mathrm{C} / \mathrm{min}$ were mainly due to an overshoot, which was reduced to $0.5^{\circ} \mathrm{C}$ within $20 \mathrm{~s}$ of holding. It is desirable to have good temperature controllability on real food samples so that an isothermal heating environment can be given for pathogen's inactivation.

Table 3 Maximum and average temperature differences in milk and beef samples at different temperatures and heating rates during the experiment

\begin{tabular}{|c|c|c|c|c|}
\hline Material & $\begin{array}{c}\text { Temperature } \\
{ }^{\circ} \mathrm{C}\end{array}$ & $\begin{array}{l}\text { Heating rate } \\
\quad{ }^{\circ} \mathrm{C} \cdot \mathrm{min}^{-1}\end{array}$ & $\begin{array}{c}\text { Average } \\
\text { temperature } \\
\text { differences } /{ }^{\circ} \mathrm{C}\end{array}$ & $\begin{array}{c}\text { Maximum } \\
\text { temperature } \\
\text { differences } /{ }^{\circ} \mathrm{C}\end{array}$ \\
\hline \multirow{9}{*}{ Milk } & \multirow{3}{*}{50.0} & 1 & 0.03 & 0.07 \\
\hline & & 5 & 0.04 & 0.14 \\
\hline & & 10 & 0.11 & 0.35 \\
\hline & \multirow{3}{*}{62.2} & 1 & 0.03 & 0.11 \\
\hline & & 5 & 0.17 & 0.25 \\
\hline & & 10 & 0.21 & 0.39 \\
\hline & \multirow{3}{*}{75.0} & 1 & 0.08 & 0.25 \\
\hline & & 5 & 0.09 & 0.25 \\
\hline & & 10 & 0.10 & 0.35 \\
\hline \multirow{9}{*}{$\begin{array}{l}\text { Ground } \\
\text { beef }\end{array}$} & \multirow{3}{*}{50.0} & 1 & 0.03 & 0.11 \\
\hline & & 5 & 0.17 & 0.39 \\
\hline & & 10 & 0.10 & 0.35 \\
\hline & \multirow{3}{*}{70.0} & 1 & 0.03 & 0.14 \\
\hline & & 5 & 0.07 & 0.18 \\
\hline & & 10 & 0.27 & 0.71 \\
\hline & \multirow{3}{*}{120.0} & 1 & 0.31 & 0.78 \\
\hline & & 5 & 0.37 & 0.84 \\
\hline & & 10 & 0.58 & 0.97 \\
\hline
\end{tabular}




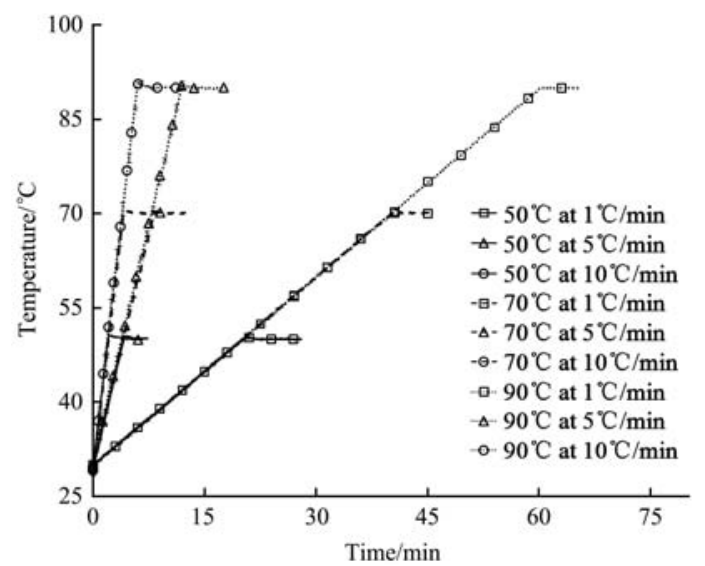

a. Apple juice

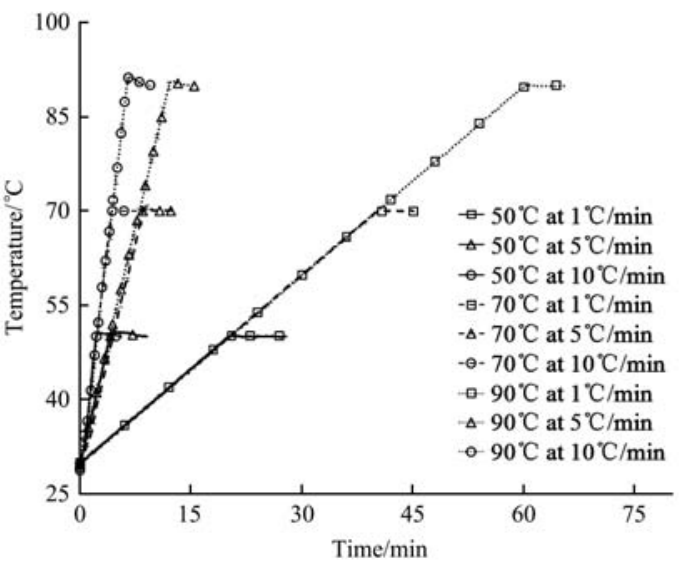

c. Rice paste

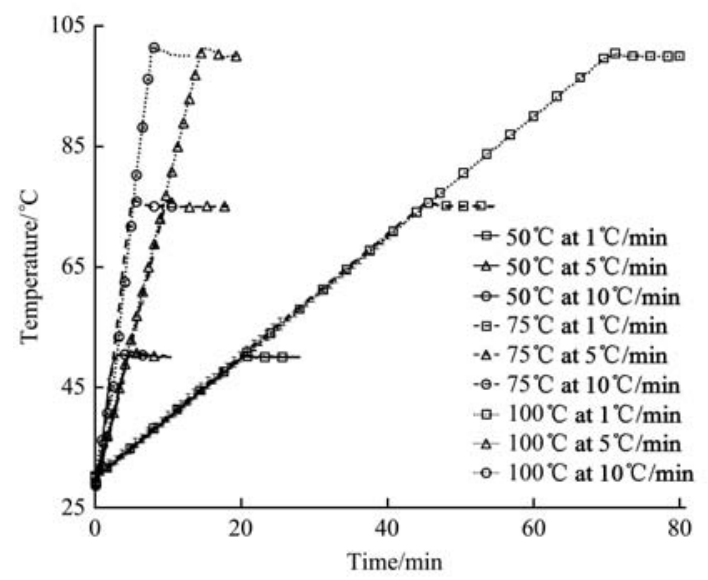

e. Peanut powder

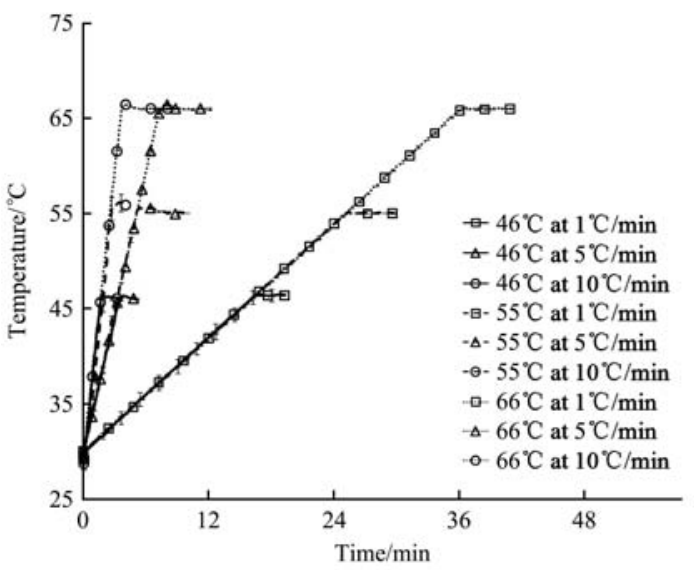

g. Egg white

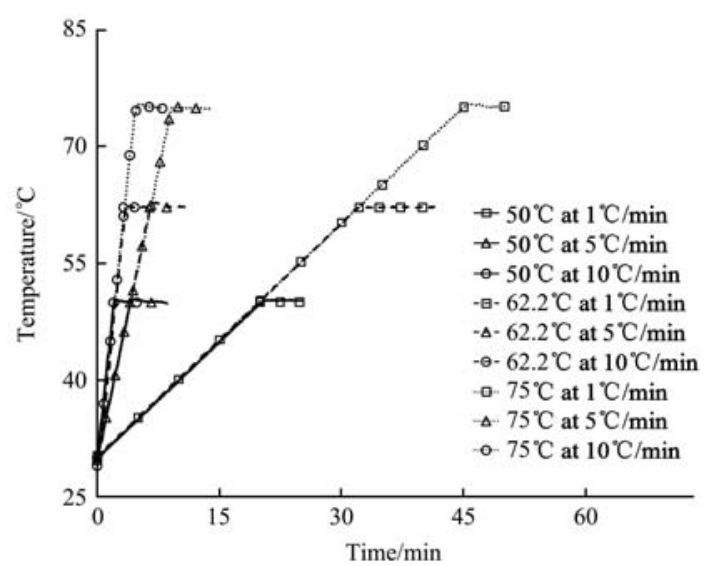

b. Milk

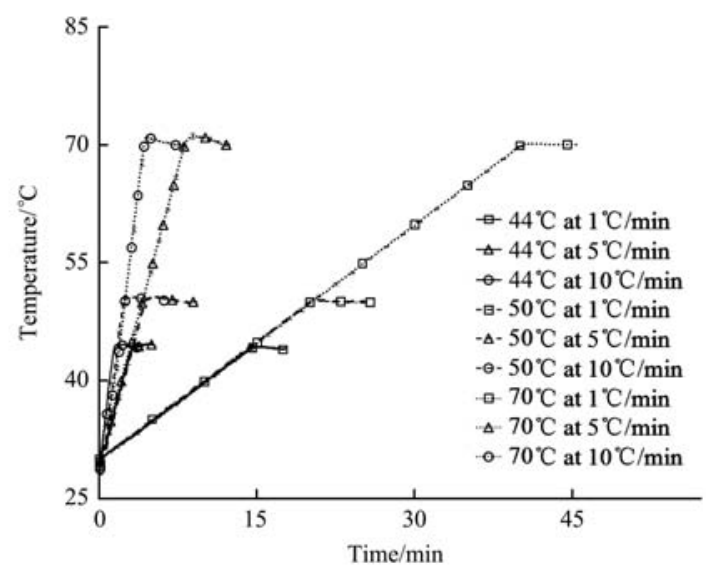

d. Rice

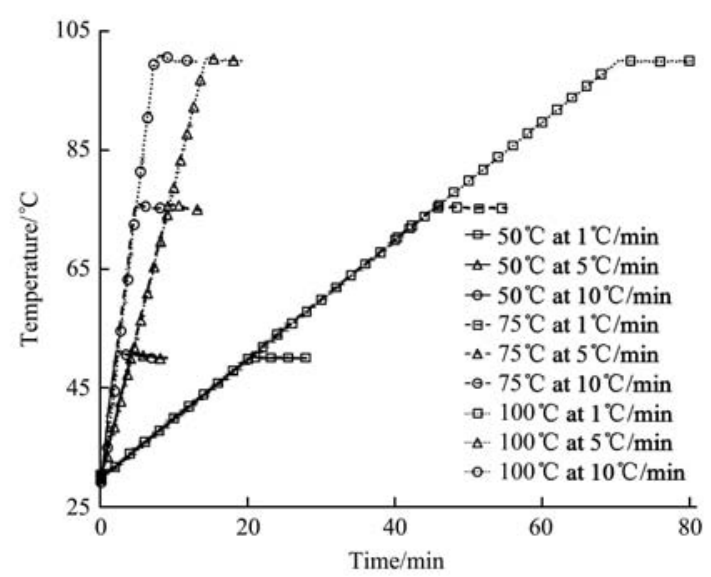

f. Peanut butter

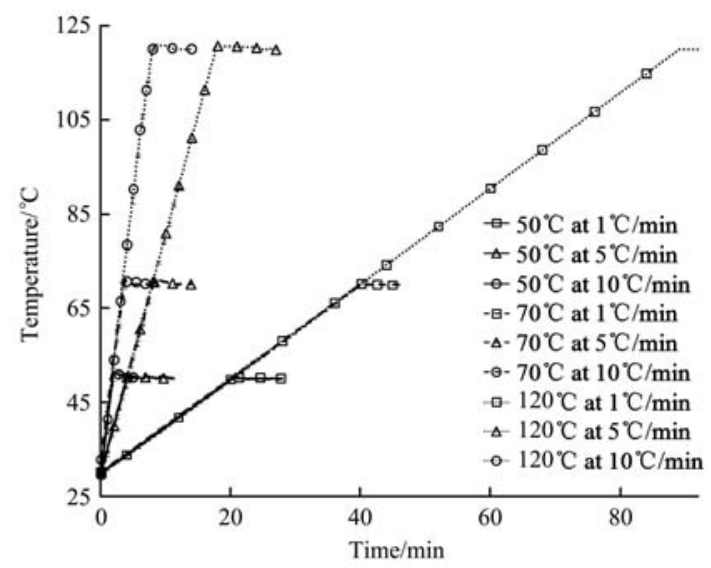

h. Ground beef

Figure 2 Experimental temperature-time histories of food samples in the HBS under three set-temperatures at three heating rates 


\subsection{Maximum heating rates}

Table 2 indicates the maximum heating rates obtained in HBS for eight food samples. The maximum heating rate had a relationship with the specific heat capacity of the material, and basically the maximum heating rate increased with increasing the specific heat capacity. The maximum heating rates were between $11.2-13.1^{\circ} \mathrm{C} / \mathrm{min}$ among the eight tested food samples. Although being smaller than those in the apparatus reported by Foster et al. ${ }^{[40]}$, the above heating rates could be enough to simulate thermal resistance of pathogens and thermal behaviors of bulk samples when subjected to hot air, water and RF heating ${ }^{[18,41,42]}$. Specifically, the heating rates were $6.4^{\circ} \mathrm{C} / \mathrm{min}$ for $5.0 \mathrm{~kg}$ rough rice in $\mathrm{RF}$ treatment to control pests ${ }^{[43]}$, and $9.3^{\circ} \mathrm{C} / \mathrm{min}$ and $0.58^{\circ} \mathrm{C} / \mathrm{min}$ for pasteurizating $3.0 \mathrm{~kg}$ corn using $\mathrm{RF}$ treatment and hot air method, respectively ${ }^{[44]}$, which can be manageable with the HBS.

\subsection{Heating uniformity of the HBS}

Table 4 shows the experimental temperature with heating time of peanut powder in six TDT-cells under heating rates of $10^{\circ} \mathrm{C} / \mathrm{min}$ using the thermocouples. The sample temperature data in six cells agreed well with each other since the maximum and average temperature differences was $0.46^{\circ} \mathrm{C}$ and $0.32^{\circ} \mathrm{C}$ during CUT and holding time, respectively. This illustrates that the HBS could provide a sufficiently uniform heating environment in six cells. Although one cell was used to control the set-temperature, heating rate and holding time, the same heating parameters were obtained in other 5 cells. Table 5 lists the heating uniformity index of peanut powder in each cell with heating rate of $10^{\circ} \mathrm{C} / \mathrm{min}$ at different temperatures. The maximum uniformity index value was 0.024 , which was much less than that reported by Yan et al. ${ }^{[22]}$ Compared with higher set point, the lower set point achieved better heating uniformity in the TDT cells since the $\lambda$ value decreased by reducing the set point from $90^{\circ} \mathrm{C}$ to $50^{\circ} \mathrm{C}$. For example, the $\lambda$ value was $0.011,0.014$ and 0.020 with set point at $50^{\circ} \mathrm{C}, 70^{\circ} \mathrm{C}$ and $90^{\circ} \mathrm{C}$ with $10^{\circ} \mathrm{C} / \mathrm{min}$, respectively.

Table 4 Experimental temperatures with heating time of peanut powder in six TDT-cells under heating rates of $10^{\circ} \mathrm{C} / \mathrm{min}$

\begin{tabular}{|c|c|c|c|c|c|c|c|}
\hline Time/min & Cell $1 /{ }^{\circ} \mathrm{C}$ & Cell $2 /{ }^{\circ} \mathrm{C}$ & Cell $3 /{ }^{\circ} \mathrm{C}$ & Cell $4 /{ }^{\circ} \mathrm{C}$ & Cell $5 /{ }^{\circ} \mathrm{C}$ & Cell $6 /{ }^{\circ} \mathrm{C}$ & SD \\
\hline 0 & $30.45 \pm 0.07$ & $29.70 \pm 0.14$ & $29.60 \pm 0.14$ & $30.00 \pm 0.21$ & $29.55 \pm 0.07$ & $29.40 \pm 0.14$ & 0.38 \\
\hline 0.5 & $35.15 \pm 0.07$ & $35.40 \pm 0.42$ & $35.35 \pm 0.07$ & $35.20 \pm 0.14$ & $34.40 \pm 0.14$ & $35.20 \pm 0.14$ & 0.36 \\
\hline 1.0 & $39.85 \pm 0.21$ & $40.95 \pm 0.28$ & $40.80 \pm 0.14$ & $40.45 \pm 0.35$ & $40.40 \pm 0.14$ & $40.70 \pm 0.28$ & 0.39 \\
\hline 1.5 & $45.25 \pm 0.35$ & $45.95 \pm 0.35$ & $45.70 \pm 0.14$ & $45.95 \pm 0.28$ & $46.20 \pm 0.14$ & $45.65 \pm 0.35$ & 0.33 \\
\hline 2.0 & $50.95 \pm 0.42$ & $50.95 \pm 0.21$ & $50.70 \pm 0.00$ & $51.00 \pm 0.35$ & $51.55 \pm 0.07$ & $50.50 \pm 0.28$ & 0.35 \\
\hline 2.5 & $56.00 \pm 0.42$ & $56.00 \pm 0.28$ & $55.70 \pm 0.00$ & $56.15 \pm 0.21$ & $56.55 \pm 0.07$ & $55.55 \pm 0.07$ & 0.35 \\
\hline 3.0 & $60.65 \pm 0.35$ & $60.95 \pm 0.21$ & $60.80 \pm 0.00$ & $61.15 \pm 0.14$ & $61.40 \pm 0.00$ & $60.50 \pm 0.14$ & 0.33 \\
\hline 3.5 & $65.75 \pm 0.42$ & $65.80 \pm 0.28$ & $65.60 \pm 0.14$ & $66.10 \pm 0.28$ & $66.55 \pm 0.07$ & $65.60 \pm 0.28$ & 0.37 \\
\hline 4.0 & $70.00 \pm 0.35$ & $70.60 \pm 0.00$ & $70.60 \pm 0.14$ & $70.70 \pm 0.35$ & $70.85 \pm 0.07$ & $70.60 \pm 0.14$ & 0.29 \\
\hline 4.5 & $70.30 \pm 0.00$ & $70.15 \pm 0.07$ & $70.05 \pm 0.07$ & $70.25 \pm 0.35$ & $70.35 \pm 0.21$ & $69.75 \pm 0.00$ & 0.22 \\
\hline 5.0 & $70.30 \pm 0.14$ & $70.35 \pm 0.14$ & $70.25 \pm 0.00$ & $70.25 \pm 0.00$ & $70.40 \pm 0.21$ & $69.90 \pm 0.14$ & 0.18 \\
\hline
\end{tabular}

Table 5 Comparison of the heating uniformity index of each cell with heating rate of $10^{\circ} \mathrm{C} / \mathrm{min}$ at different temperatures using peanut powder sample

\begin{tabular}{ccccccc}
\hline Temperature & Cell 1 & Cell 2 & Cell 3 & Cell 4 & Cell 5 & \\
\hline $50^{\circ} \mathrm{C}$ & $0.011 \pm 0.002$ & $0.009 \pm 0.001$ & $0.015 \pm 0.004$ & $0.006 \pm 0.004$ & $0.011 \pm 0.001$ \\
$70^{\circ} \mathrm{C}$ & $0.014 \pm 0.003$ & $0.011 \pm 0.001$ & $0.021 \pm 0.004$ & $0.012 \pm 0.001$ & $0.012 \pm 0.003$ \\
$90^{\circ} \mathrm{C}$ & $0.020 \pm 0.002$ & $0.015 \pm 0.004$ & $0.024 \pm 0.001$ & $0.013 \pm 0.001$ & $0.009 \pm 0.001$ & $0.018 \pm 0.004$ \\
\hline
\end{tabular}

\subsection{Finite element simulation and validation}

Figure 3 compares simulated and measured temperature profiles with heating rates of $5^{\circ} \mathrm{C} / \mathrm{min}$ and $10^{\circ} \mathrm{C} / \mathrm{min}$ in apple juice, milk, rice paste, rice, egg white, peanut powder, peanut butter and ground beef. The sample temperature increased lineally with the heating time using the HBS $\left(R^{2}=0.99\right)$. For all heating rates and set-points, simulated data agreed well with experimental temperatures since the maximum and average temperature differences were $0.91{ }^{\circ} \mathrm{C}$ and $0.16^{\circ} \mathrm{C}$, respectively, between experiment and simulation during CUT. The thermal properties including specific heat and thermal conductivity were important factors used in the simulation, thus the temperature differences mentioned above were mainly caused by the constant thermal properties used in the experiment. More accurately results from the model could be achieved when the temperature-dependent thermal properties were provided by direct measurements.

Figure 4 shows experimental and simulated temperature distributions at contour plot of a central cross-section of peanut powder samples with the heating rate of $10^{\circ} \mathrm{C} / \mathrm{min}$. The results demonstrated that the simulated temperature distribution patterns were in good agreement with the experimental ones. The simulated temperatures were slightly higher than the experimental values, probably due to slight heat loss from the experimental samples to the environment before temperature mapping ${ }^{[45]}$. This illustrates that the model parameters were adequately inputted for estimating actual heat transfers within the HBS, and the validated model could be further used to predict temperature distributions during the thermal process.

\subsection{Comparison between the HBS and RF thermal process}

Figure 5 shows the temperature-time histories of walnut sample in the HBS and RF heating. The temperature profile obtained by the HBS was in good agreement with that in RF treatment. The maximum temperature difference was about $0.85^{\circ} \mathrm{C}$, which could be further reduced by increasing the number of line segments. The results indicated that the HBS could simulate the similar heating process of RF energy. The system can serve as a reliable experimental tool for studying the inactivation kinetics of food-borne pathogens on real foods under real processing conditions to simulate the common thermal processes using hot air, hot water, RF energy and so on. The unique feature of the HBS may help in more precisely characterizing the heat resistance of pathogens in foods to further develop pasteurization processes. 


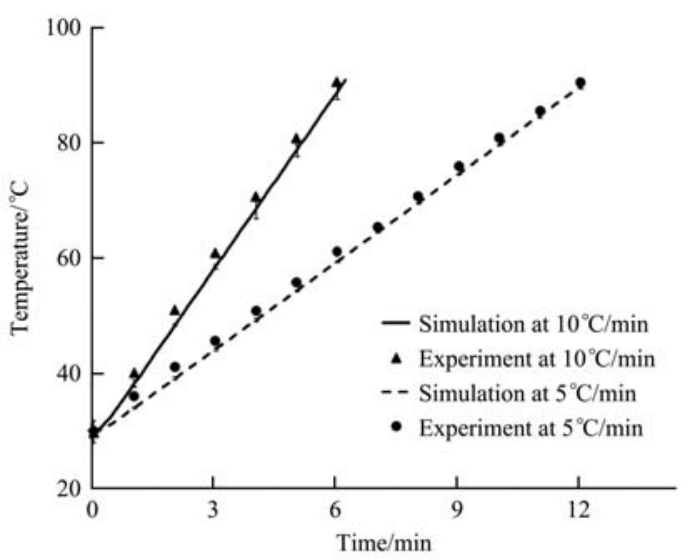

a. Apple juice

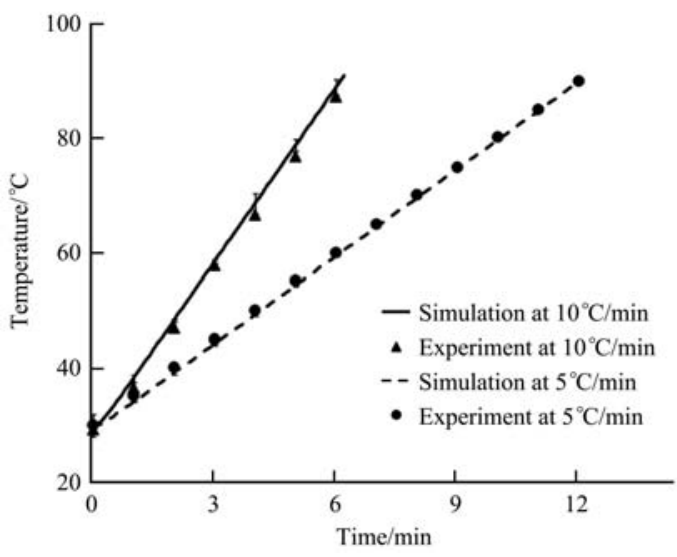

c. Rice paste

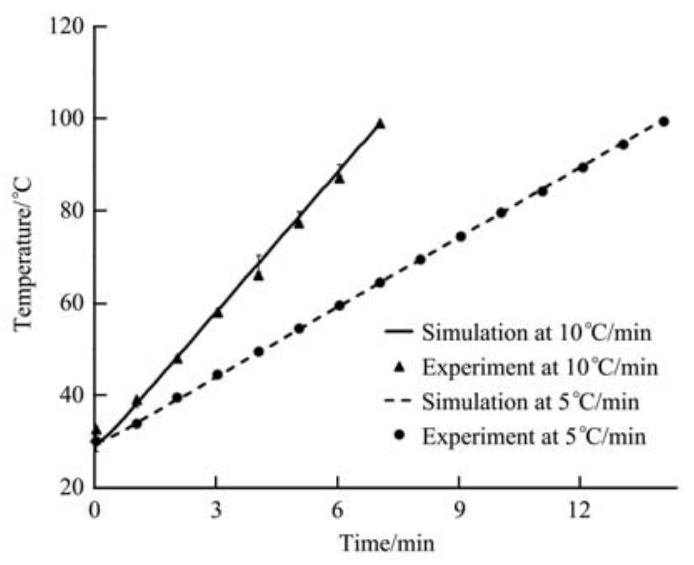

e. Peanut powder

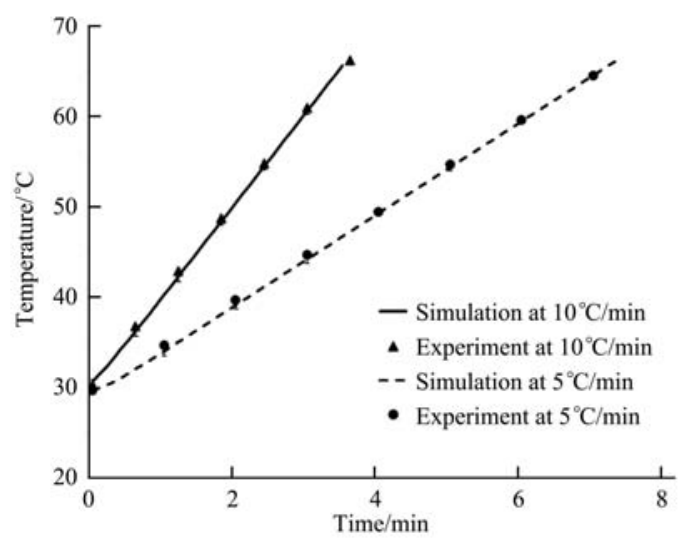

g. Egg white

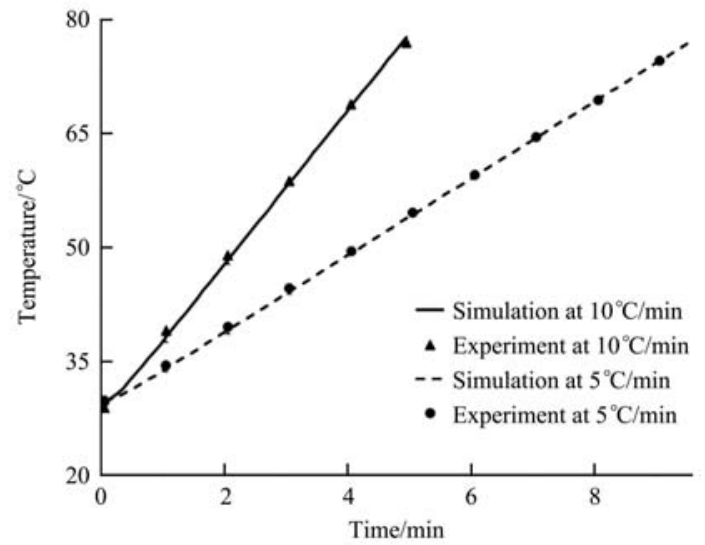

b. Milk

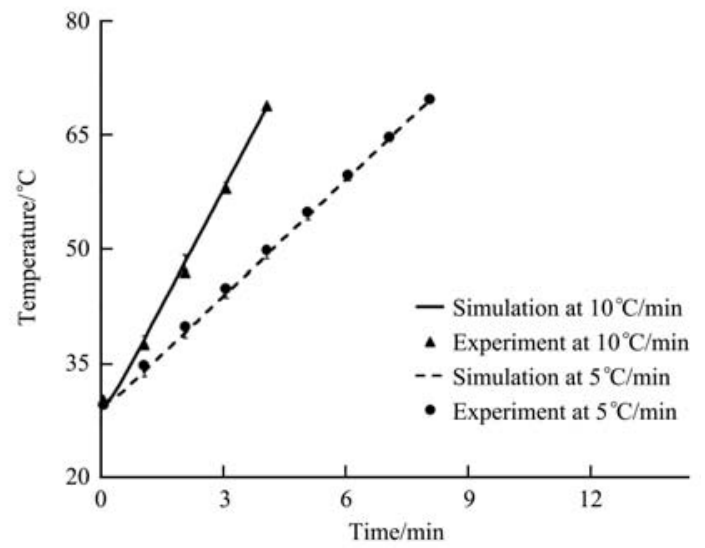

d. Rice

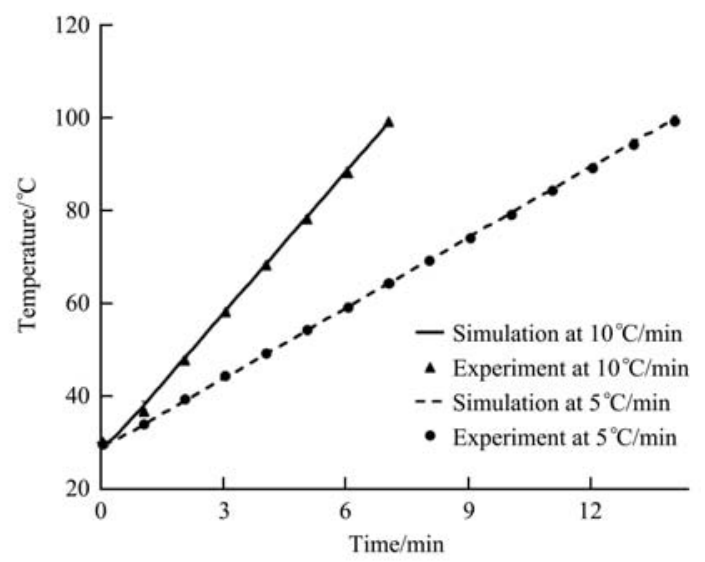

f. Peanut butter

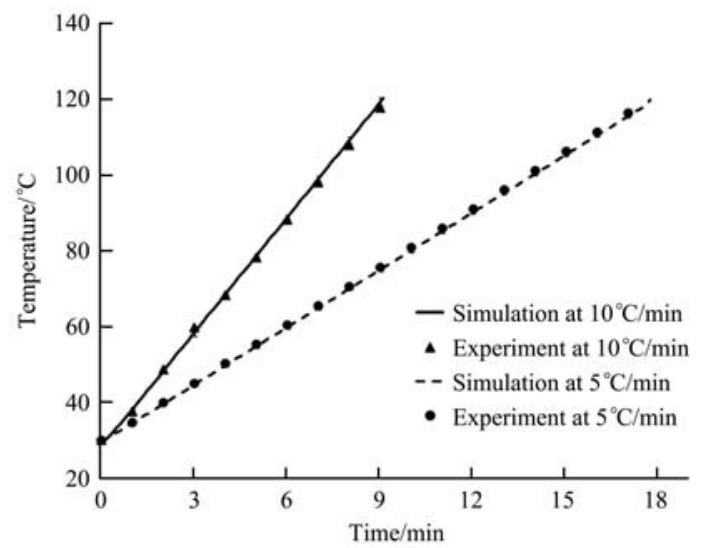

h. Ground beef

Figure 3 Comparison between simulated and measured temperature profiles at heating rates of $5^{\circ} \mathrm{C} / \mathrm{min}$ and $10^{\circ} \mathrm{C} / \mathrm{min}$ in food samples at $50^{\circ} \mathrm{C}, 75^{\circ} \mathrm{C}$ and $100^{\circ} \mathrm{C}$ 


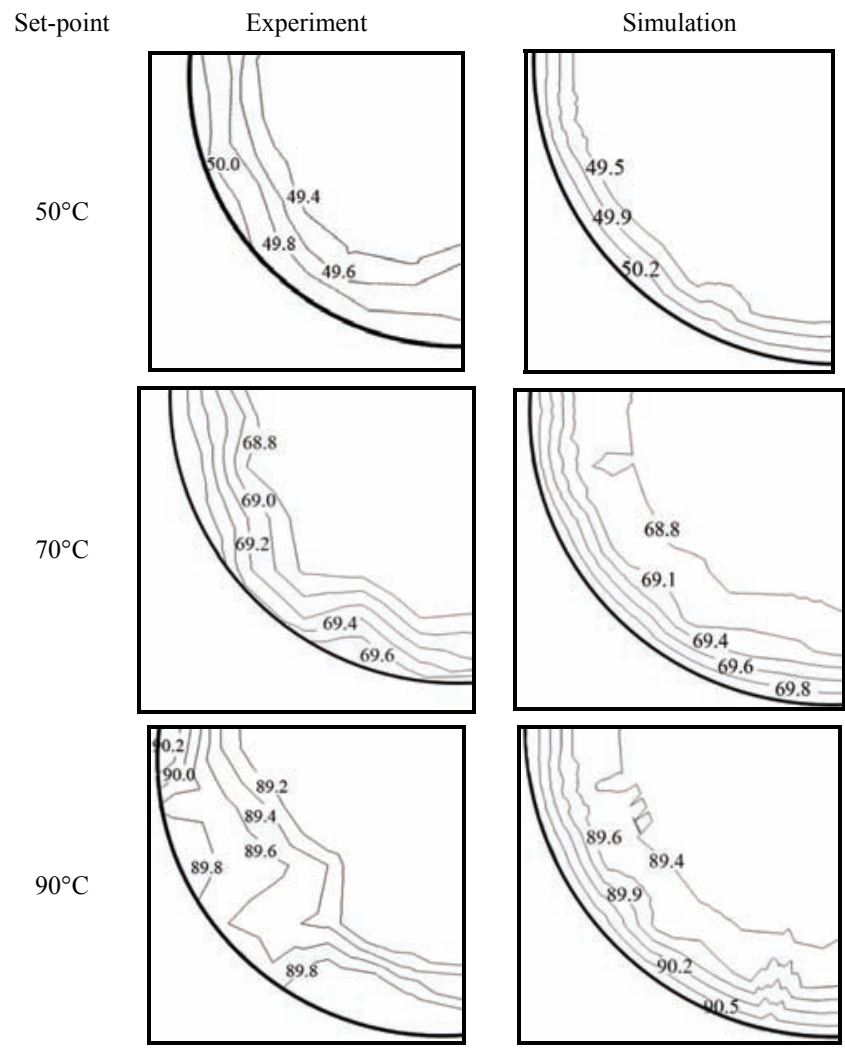

Figure 4 Experimental and simulated temperature distributions at contour plot of a central cross-section of peanut powder samples with the heating rate of $10^{\circ} \mathrm{C} / \mathrm{min}$

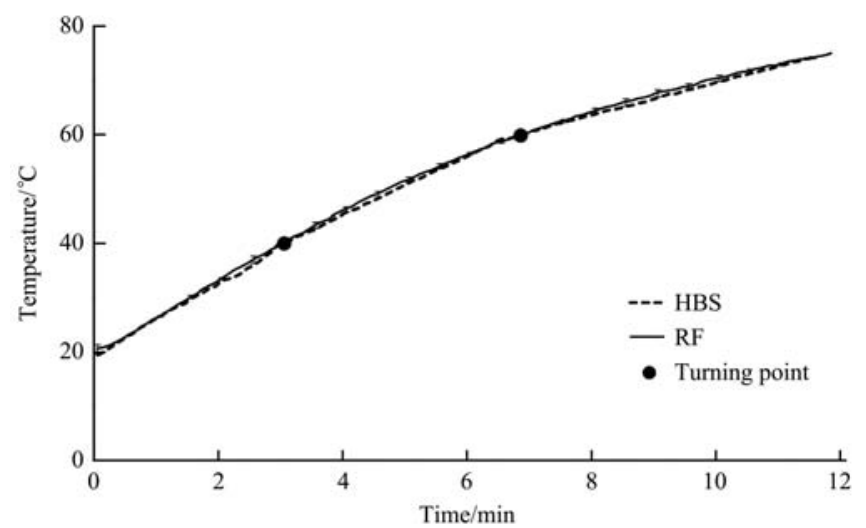

Figure 5 Temperature-time histories of walnut samples heated by the RF system and the HBS

\section{Conclusions}

The TDT HBS was a unique experimental system developed to simulate a wide range of controlled set-temperatures, heating rates and holding time in various types of food. Stability of temperatures and heating rates in eight different foods were good enough for pathogen's TDT test during the thermal process and holding time. The experimental and simulated results showed that the HBS could provide a sufficiently uniform heating environment over the six cells. The real temperature-time histories obtained by $\mathrm{RF}$, hot water, and hot air heating could be simulated in HBS by setting a number of linear regression curves. This HBS can be implemented for determining the thermal inactivation kinetic models of the target pathogens as influenced by various important factors (heating rates, initial temperature, water activity, and so on). HBS proposed in the study can be further used to identify the thermal and non-thermal effects of RF treatments in the near future.

\section{Acknowledgements}

This research was conducted in the College of Mechanical and Electronic Engineering, Northwest A\&F University, and supported by research grants from General Program of National Natural Science Foundation of China (31371853) and National Key Research and Development Program of China (2016YFD0401000).

\section{[References]}

[1] [CDCP] Centers for Disease Control and Prevention. Multistate outbreak of Salmonella bredeney infections linked to peanut butter manufactured by Sunland, 2013. Available: http://www.cdc.gov/salmonella/bredeney09-12/. Accessed on [2017-08-21].

[2] Ha J W, Kim S Y, Ryu S R, Kang D H. Inactivation of Salmonella enterica serovar Typhimurium and Escherichia coli $\mathrm{O} 157: \mathrm{H} 7$ in peanut butter cracker sandwiches by radio-frequency heating. Food Microbiology, 2013; 34(1): 145-150.

[3] Gao M, Tang J, Villa-Rojas R, Wang Y, Wang S. Pasteurization process development for controlling Salmonella in in-shell almonds using radio frequency energy. Journal of Food Engineering, 2011; 104(2): 299-306.

[4] Kim S Y, Sagong H G, Choi S H, Ryu S, Kang D H. Radio-frequency heating to inactivate Salmonella Typhimurium and Escherichia coli O157:H7 on black and red pepper spice. International Journal of Food Microbiology, 2012; 153(1-2): 171-175.

[5] Lee S Y, Sagong H G, Ryu S, Kang D H. Effect of continuous ohmic heating to inactivate Escherichia coli O157:H7, Salmonella Typhimurium and Listeria monocytogenes in orange juice and tomato juice. Journal of Applied Microbiology, 2012; 112(4): 723-731.

[6] Ling B, Tang J, Kong F, Mitcham E J, Wang S. Kinetics of food quality changes during thermal processing: A review. Food and Bioprocess Technology, 2015; 8(2): 343-358.

[7] Stoforos N G. Thermal process design. Food Control, 1995; 6(2): 81-94.

[8] Zheng A, Zhang L, Wang S. Verification of radio frequency pasteurization treatment for controlling Aspergillus parasiticus on corn grains. International Journal of Food Microbiology, 2017; 249: 27-34.

[9] Büchner C, Thomas S, Jaros D, Rohm H. Fast-responding thermal - death - time tubes for the determination of thermal bacteria inactivation. Engineering in Life Sciences, 2012; 12(1): 109-112.

[10] Odlaug T E, Pflug I J. Thermal destruction of Clostridium botulinum spores suspended in tomato juice in aluminum thermal death time tubes. Applied and Environmental Microbiology, 1977; 34(1): 23-29.

[11] Chung H J, Wang S, Tang J. Influence of heat transfer with tube methods on measured thermal inactivation parameters for Escherichia coli. Journal of Food Protection, 2007; 70(4): 851-859.

[12] Chung H J, Birla S L, Tang J. Performance evaluation of aluminum test cell designed for determining the heat resistance of bacterial spores in foods. LWT - Food Science and Technology, 2008; 41(8): 1351-1359.

[13] Li R, Shi Y, Ling B, Cheng T, Huang Z, Wang S. Thermo-tolerance and heat shock protein of Escherichia coli ATCC 25922 under thermal stress using test cell method. Emirates Journal of Food and Agriculture, 2017; 29(2): 91

[14] Juneja V K. A comparative heat inactivation study of indigenous microflora in beef with that of Listeria monocytogenes, Salmonella serotypes and Escherichia coli O157:H7. Letters in Applied Microbiology, 2003; 37(4): 292-298.

[15] Smith S E, Maurer J L, Ortaramirez A, Ryser E T, Smith D M. Thermal inactivation of Salmonella spp., Salmonella typhimurium DT104, and Escherichia coli O157:H7 in ground beef. Microbiología, 2001; 12(12): 525-536.

[16] Khoo K Y, Davey K R, Thomas C J. Assessment of four model forms for predicting thermal inactivation kinetics of Escherichia coli in liquid as affected by combined exposure time, liquid temperature and $\mathrm{pH}$. Food and Bioproducts Processing, 2003; 81(2): 129-137.

[17] Ach S, Delgadopando G, Linton M, Patterson M F, Koidis A. Industrial scale microwave processing of tomato juice using a novel continuous microwave system. Food Chemistry, 2016; 190: 622-645.

[18] Awuah G, Ramaswamy H, Economides A, Mallikarjunan K. Inactivation of Escherichia coli $\mathrm{K}-12$ and Listeria innocua in milk using radio frequency (RF) heating. Innovative Food Science \& Emerging Technologies, 2005; 6(4): 396-402.

[19] Li R, Kou X, Cheng T, Zheng A, Wang S. Verification of radio 
frequency pasteurization process for in-shell almonds. Journal of Food Engineering, 2017; 192: 103-110.

[20] Kou X X, Li R, Hou L X, Huang Z, Ling B, Wang S J. Performance of a heating block system designed for studying the heat resistance of bacteria in foods. Scientific Reports, 2016; 6:1-12.

[21] Yuk H-G, Geveke D J, Zhang H Q, Jin T Z. Comparison of aluminum thermal-death-time disks with a pilot-scale pasteurizer on the thermal inactivation of Escherichia coli K12 in apple cider. Food Control, 2009; 20(11): 1053-1057.

[22] Yan R, Huang Z, Zhu H, Johnson J A, Wang S. Simulation of heating uniformity in a heating block system modified for controlled atmosphere treatments. Journal of Stored Products Research, 2016; 65: 19-29.

[23] Huang Z, Chen L, Wang S. Computer simulation of radio frequency selective heating of insects in soybeans. International Journal of Heat and Mass Transfer, 2015; 90: 406-417.

[24] Huang Z, Zhang B, Marra F, Wang S. Computational modelling of the impact of polystyrene containers on radio frequency heating uniformity improvement for dried soybeans. Innovative Food Science \& Emerging Technologies, 2016; 33: 365-380.

[25] Arroyo C, Cebrian G, Pagan R, Condon S. Synergistic combination of heat and ultrasonic waves under pressure for Cronobacter sakazakii inactivation in apple juice. Food Control, 2012; 25(1): 342-348.

[26] Gabriel A A, Nakano H. Effects of culture conditions on the subsequent heat inactivation of E. coli $\mathrm{O} 157: \mathrm{H} 7$ in apple juice. Food Control, 2011; 22(8): 1456-1460.

[27] Chen H. Use of linear, Weibull, and log-logistic functions to model pressure inactivation of seven foodborne pathogens in milk. Food Microbiology, 2007; 24(3): 197-204.

[28] Zhou L, Ling B, Zheng A, Zhang B, Wang S. Developing radio frequency technology for postharvest insect control in milled rice. Journal of Stored Products Research, 2015; 62: 22-31.

[29] Zhou L Y, Wang S J. Verification of radio frequency heating uniformity and Sitophilus oryzae control in rough, brown, and milled rice. Journal of Stored Products Research, 2016; 65: 40-47.

[30] Li C, Huang L, Chen J. Comparative study of thermal inactivation kinetics of Salmonella spp. in peanut butter and peanut butter spread. Food Control, 2014; 45: 143-149.

[31] Bazhal M I, Ngadi M O, Raghavan G S V, Smith J P. Inactivation of Escherichia coli $\mathrm{O} 157: \mathrm{H} 7$ in liquid whole egg using combined pulsed electric field and thermal treatments. LWT - Food Science and Technology, 2006; 39(4): 420-426.

[32] Jin T, Zhang H, Boyd G, Tang J. Thermal resistance of Salmonella enteritidis and Escherichia coli $\mathrm{K} 12$ in liquid egg determined by thermal-death-time disks. Journal of Food Engineering, 2008; 84(4):
608-614.

[33] Jackson T C, Hardin M D, Acuff G R. Heat resistance of Escherichia coli $\mathrm{O} 157$ : $\mathrm{H} 7$ in a nutrient medium and in ground beef patties as influenced by storage and holding temperatures. Journal of Food Protection, 1996; 59(3): 230-237.

[34] Juneja V, Mukhopadhyay S, Marks H, Mohr T B, Warning A, Datta A. Predictive thermal inactivation model for effects and interactions of temperature, $\mathrm{NaCl}$, sodium pyrophosphate, and sodium lactate on Listeria monocytogenes in ground beef. Food and Bioprocess Technology, 2014; 7(2): 437-446.

[35] Wang S, Yue J, Tang J, Chen B. Mathematical modelling of heating uniformity for in-shell walnuts subjected to radio frequency treatments with intermittent stirrings. Postharvest Biology and Technology, 2005; 35(1): 97-107.

[36] Krokida M K, Panagiotou N M, Maroulis Z B, Saravacos G D. Thermal conductivity: Literature data compilation for foodstuffs. International Journal of Food Properties, 2001; 4, 111-137.

[37] Sahin S, Sumnu S G. Thermal properties of foods. In Sahin S et al. (Eds.), Physical properties of foods. New York: Elsevier, 2006; pp. 127-140.

[38] Tavman I H, Tavman S. Measurement of thermal conductivity of dairy products. Journal of Food Engineering, 1999; 41, 109-114.

[39] Ikediala J, Tang J, Wig T. A heating block system for studying thermal death kinetics of insect pests. Trans of the ASAE, 2000; 43(2): 351-358.

[40] Foster A M, Ketteringham L P, Purnell G L, Kondjoyan A, Havet M, Evans J A. New apparatus to provide repeatable surface temperature-time treatments on inoculated food samples. Journal of Food Engineering, 2006; 76(1): 19-26.

[41] Liu Y, Tang J, Mao Z, Mah J-H, Jiao S, Wang S. Quality and mold control of enriched white bread by combined radio frequency and hot air treatment. Journal of Food Engineering, 2011; 104(4): 492-498.

[42] Wang S, Tang J, Cavalieri R P. Modeling fruit internal heating rates for hot air and hot water treatments. Postharvest Biology and Technology, 2001; 22(3): 257-270.

[43] Zhou L, Wang S. Industrial-scale radio frequency treatments to control Sitophilus oryzae in rough, brown, and milled rice. Journal of Stored Products Research, 2016; 68: 9-18.

[44] Zheng A, Zhang B, Zhou L, Wang S. Application of radio frequency pasteurization to corn (Zea mays L.): Heating uniformity improvement and quality stability evaluation. Journal of Stored Products Research, 2016; 68: 63-72.

[45] Huang Z, Zhu H, Wang S. Finite element modelling and analysis of radio frequency heating rate in mung beans. Trans of the ASAE, 2015; 58(1): 149-160. 